\title{
Renin-Angiotensin-Aldosteronsystem und Wasserhaushalt bei Gestose während der tokolytischen Therapie
}

G. Grospietsch, M. Fenske, J. Girndt, W. Kuhn, Göttingen

Während der tokolytischen Therapie mit $\beta_{2}$-Sympathomimetika treten gelegentlich schwere Wassereinlagerungen und Lungenödeme auf. Dies was Anlaß zu Untersuchungen des Wasserhaushaltes und des Renin-Angiotensinsystems bei gesunden Schwangeren und Schwangeren mit einer Gestose.

Methotik: Untersucht wurden 18 gesunde Schwangere und zehn Patientinnen mit einer Gestose. Parameter: 1. Blut, Serum, Plasma: Hb, Hk, Eiweiß, Natrium, Kalium, Kreatinin, Plasma-Reninaktivität (PRA), Aldosteron (A). 2. Urin, Harnzeitvolumen, Natrium, Kalium, Kreatinin. 3. Körpergewichtsveränderungen. Der Zeitraum der Untersuchungen betrug 24 Std.

Ergebnisse: Bei allen Patientinnen zeigte sich eine deutliche Abnahme der Urinund Elektrolytausscheidung und der Kreatinin-Clearance. Dies bedeutet eine Flüssigkeitseinlagerung. Sie zeigt sich im Anstieg des Körpergewichtes, in einem Abfall des $\mathrm{Hb}$, Hk und des Gesamteiweißes. Die PRA steigt an bei abfallenden A-Werten. Dieser Abfall ist gleichsinnig zu den ebenfalls absinkenden Serumkaliumwerten. Der Serumnatriumwert bleibt gleich. Die Patientinnen mit einer Gestose unterscheiden sich in vier Punkten deutlich von den übrigen Patientinnen.

1. Die Urinausscheidung ist um $30 \%$ vermindert. 2. Die Natriumausscheidung ist um $10 \%$ vermindert. 3. Der Gewichtsanstieg beträgt $1,7 \mathrm{~kg} / 24 \mathrm{Std}$ gegenüber $1,1 \mathrm{~kg} / 24 \mathrm{Std}$ bei den Patientinnen mit einer normalen Gravidität. 4. Die PRA ist extrem erhöht.

Diskussion: Während der tokolytischen Therapie mit $\beta_{2}$-Sympathomimetika kommt es zu einer deutlichen Wasserretention, die bei Patientinnen mit einer Gestose wesentlich stärker ist. Die vorliegenden Untersuchungen und eigene Tierexperimente weisen darauf hin, daß die Lungenödeme durch eine Überwässerung entstehen und Patientinnen mit einer Gestose, da sie einen hohen Ausgangswert interstitiell gebundener Flüssigkeit besitzen und bei der tokolytischen Therapie zu etwa 30\% mehr Wasser retinieren, schon bei relativ geringer Flüssigkeitszufuhr zur Überwässerung und zum Lungenödem neigen. 